\title{
Genome size variation in Deschampsia cespitosa sensu lato (Poaceae) in Eurasia
}

\author{
Josef Greimler ${ }^{1} \mathbb{D}$ - Eva M. Temsch ${ }^{1} \cdot$ Zhiqing Xue $^{1} \cdot$ Hanna Weiss-Schneeweiss ${ }^{1} \cdot$ Polina Volkova $^{2}$. \\ Markus Peintinger ${ }^{3} \cdot$ Pawel Wasowicz $^{4} \cdot$ Hui Shang ${ }^{5} \cdot$ Ivan Schanzer $^{6} \cdot$ Jorge O. Chiapella $^{7}$
}

Received: 2 April 2021 / Accepted: 16 November 2021 / Published online: 7 January 2022

(C) The Author(s) 2022

\begin{abstract}
The grass Deschampsia cespitosa is a variable taxon out of which many varieties, subspecies and endemic species have been separated. In this paper, the variation in genome size (GS) and ploidy of this grass including several of its subspecies and two related species in Eurasia was investigated by flow cytometric (FCM) measurements. GS and ploidy data were also related to specific environments and reproduction mode. Ploidy levels found by FCM were confirmed by chromosome counts of diploid $(2 n=28)$ and tetraploid $(2 n=52)$ samples. Seminiferous (seed bearing) D. cespitosa was mainly diploid (GS between 3.754 and $5.438 \mathrm{pg} / 1 \mathrm{C}$ ). GS variation in diploids showed a geographic pattern with a significant difference $(H=41,441, P<0.001)$ between European (median $=4.377 \mathrm{pg})$ and Asian (median $=4.881 \mathrm{pg})$ accessions. Genome size (1C) in tetraploids ranged from 7.9426 to $9.0399 \mathrm{pg}$. Tetraploid seminiferous D. cespitosa was found mostly in disturbed habitats in western and southern Europe, while tetraploids in Asia were registered in wet Arctic habitats. Genome size (1C between 8.3278 and $8.8603 \mathrm{pg}$ ) of the pseudoviviparous plants (spikelets produce plantlets asexually) of wet habitats in central and northern Europe indicated tetraploidy. A putative triploid (GS $6.6817 \mathrm{pg}$ ) was detected in Iceland. Summing up, we found a high variation in GS on the geographic scale with significant regional differences in diploid $D$. cespitosa. Among the tetraploids, the asexually reproducing plants were bound to specific habitats, while the seminiferous plants showed a habitat preference similar to the diploids.
\end{abstract}

Keywords Deschampsia $\cdot$ Flow cytometry $\cdot$ Genome size $\cdot$ Geographical variation $\cdot$ Polyploidy $\cdot$ Pseudovivipary

Handling editor: Jorg Fuchs.

Josef Greimler

josef.greimler@univie.ac.at

1 Department für Botanik und Biodiversitätsforschung, Universität Wien, Rennweg 14, 1030 Wien, Austria

2 Papanin Institute for Biology of Inland Waters RAS, Yaroslavl Region, Borok 152742, Russia

3 WSL Swiss Federal Research Institute, Zürcherstrasse 111, CH-8903 Birmensdorf, Switzerland

4 Icelandic Institute of Natural History (Náttúrufræðistofnun Íslands), Borgir vid Nordurslod, 600 Akureyri, Iceland

5 Shanghai Chenshan Plant Science Research Center, Chinese Academy of Sciences, Shanghai Chenshan Botanical Garden, Shanghai, 201602, China

6 Tsitsin Main Botanical Garden of Russian Academy of Sciences, Botanicheskaya U1. 4, Moscow 127276, Russia

7 Instituto de Investigaciones en Biodiversidad y Medioambiente (INIBIOMA-CONICET-Universidad Nacional del Comahue), Quintral 1250, R8400FRF Bariloche, Río Negro, Argentina

\section{Introduction}

There is increasing evidence that all plant lineages have undergone several whole-genome doubling (WGD) events, i.e., cycles of polyploidization (e.g., Jiao et al. 2011; Soltis et al. 2014; Wendel et al. 2018) although the exact number and timing of these events are still disputed (Ruprecht et al. 2017). From analyzing the whole-genome data of major lineages, Jiao et al. (2011) infer at least two events of ancient whole-genome duplications to have occurred about 319 and 192 million years ago; this is long before the divergence of monocots and eudicots. Further duplications within various lineages provided raw material for plant evolution, which makes the study of its relationship with lineage diversification essential (Weiss-Schneeweiss and Schneeweiss 2013).

Grasses (Poaceae) are among those groups that have experienced ancient WGDs (Jiao et al. 2011) affecting the entire family, and further ancient or more recent polyploidizations in several lineages such as those in Andropogon 
gerardii Vitman (Keeler and Davis 1999), in the genera Hordeum L. (Eilam et al. 2009), as well as in Zea L. and Triticum L. (Kellogg 2015), have played a major role in evolution. The genus Deschampsia is another group experiencing polyploidization followed by chromosomal rearrangements (Amosova et al. 2017), as evidenced also by different ploidy levels, chromosome numbers (Amosova et al. 2015, 2017) and a high variation in genome size (1C from 5 to $5.5 \mathrm{pg}$ ) for diploids (Bennett et al. 1982; Murray et al. 2005; PascualDíaz et al. 2020). However, we found only one value for a tetraploid plant $(1 \mathrm{C}=9 \mathrm{pg})$ reported by Bennett et al. (1982). The basic chromosome number of the genus $(x=13)$ differs from other members of the core Pooideae (mostly $x=7$ ), suggesting polyploidy incidence predating the diversification of the genus. In the traditional narrow sense, with exclusion of taxa formerly ascribed to Deyeuxia Clarion ex P.Beauv (Saarela et al. 2017) and Scribneria Hack (Soreng et al. 2015), Deschampsia comprises ca. 30 species of mostly perennials and a few South American annual species (Chiapella and Zuloaga 2010). Hybridization and reticulate evolution are common in this group of grasses (Wölk and Röser 2017) and might obscure phylogenetic relationships that are traditionally based on only a few selected molecular markers.

Deschampsia cespitosa (L.) P.Beauv., the tufted hair grass, is the most common species of the genus, found in all continents, with a disjunct distribution among the northern hemisphere landmasses, southern South America, Australasia and South Africa. Deschampsia cespitosa is a tussockforming, wind-pollinated, self-incompatible grass, occurring in habitats with moderate to high moisture in a cold-temperate climate. This grass has established populations in similar habitats in regions separated by thousands of kilometers, where appropriate ecological conditions are present.

\section{Taxonomic challenges}

The high morphological variation of Deschampsia cespitosa has led to a confusing taxonomy in the northern hemisphere (e.g., Böcher et al. 1968; Porsild and Cody 1980) where several Central European populations in particular ecological settings have been treated as narrow endemic species (Conert 1987; Lauber and Wagner, 1998), or subspecies (Chiapella 2000). Intergradation and hybridization between geographic variants that may be considered subspecies were assumed by Clarke (1978). Taxa from Russia and eastern Asia were also treated either as different species (Probatova 1985; Czerepanov 1995; Tzvelev and Probatova 2012) or as infraspecific taxa by Chiapella and Probatova (2003). Several endemic taxa were described by Tzvelev et al. (2015) and Tzvelev and Probatova (2019). In contrast, the lumping treatment in the Flora of China $(\mathrm{Wu}$ and Phillips 2006) recognizes only two species (D. koelerioides Regel and D. cespitosa) with four subspecies of
D. cespitosa. The occurrence of pseudovivipary or facultative pseudovivipary has further complicated systematic approaches. With this form of clonal reproduction, the entire spikelet is transformed into a small plantlet. Because of the unclear taxonomy, especially in the northern hemisphere, some authors (e.g., Kawano 1963; Rothera and Davy 1986) preferred to use the informal rank of $D$. cespitosa complex which includes all morphologically similar varieties, subspecies and regional species.

\section{Karyological variation}

Deschampsia cespitosa has been studied in various regional samples (e.g., Kawano 1963; Albers 1980; Garcia-Suarez et al. 1997; Murray et al. 2005; Amosova et al. 2017). Eurasian accessions of $D$. cespitosa were found to be mostly diploid with 2n=26 (Kawano 1963; Albers 1975, 1980; GarciaSuarez et al. 1997; Dobes and Vitek 2000) with occasional reports of $2 n=28$ (Kawano 1963) or $2 n=26+1 \mathrm{~B}$ (Marhold et al. 2007). Aneuploidy was reported for both the diploids (Kawano 1963) and the polyploids (tetraploids or occasionally also triploids; Kawano 1963; Albers 1980; Hedberg 1958). Deviating numbers such as $2 n=41,49,50$ (Löve and Löve 1975; Albers 1980) and $2 n=42$ (Sokolovskaya and Probatova 1975) have also occasionally been reported for the polyploids. In a detailed survey of ploidy levels in populations of $D$. cespitosa across Great Britain, both diploids and tetraploids ( $2 n=26$ and $2 n=52$, respectively) were reported by Rothera and Davy (1986). This survey revealed that tetraploids are the predominant cytotype on the island. The presence of diploids and polyploids has also been documented in several of the taxa of different ranks related to $D$. cespitosa recognized from Russia (Chiapella and Probatova 2003; Tzvelev and Probatova 2019). It has been hypothesized that morphological variation may be correlated with ploidy levels (Chiapella and Probatova 2003).

Thus, Deschampsia cespitosa provides an interesting system to study the role of polyploidy in the context of biogeographical and habitat features. Using flow cytometry (FCM), this paper reports the genome size and ploidy-level variation of multiple populations of $D$. cespitosa to (i) identify biogeographic patterns related to genome size and ploidy levels; (ii) examine to which extent ploidy is related to specific environments and asexual reproduction.

\section{Materials and methods}

\section{Plant material}

Plant leaves of 129 populations of Deschampsia cespitosa and two related species for FCM were collected in the field and dried under standard herbarium conditions. Tillers were 
also transplanted to the Botanical Garden of the University of Vienna (HBV) to provide the source of fresh leaf tissue for genome size measurements and root tips for chromosome counts. Plantlets of pseudoviviparous origin were also used for genome size measurement and grown in petri dishes for collecting root tips. Finally, fresh material was used for only a few samples from Lake Constance and for a small number of Austrian samples. The majority of samples for genome size measurement, however, was taken from the dried vouchers collected during the field trips. In a pilot test, we have followed the performance of fresh and dried leaf samples by measuring after several intervals over 5 months (data in Online Resource 1). The vast majority of our samples was stored between 3 and 4 months before processing. Vouchers of the samples are deposited in the herbaria WU and CSH (for duplicates of Chinese samples).

With the broad concept of Deschampsia cespitosa, we follow here Chiapella and Probatova (2003) and further relevant sources (Clarke 1980; Chiapella 2000; Wu and Phillips 2006) as none covers the entire investigated area (see Online Resource 2). We were not able to collect the newly described endemic taxa by Tzvelev and Probatova (2019). Regarding Europe, we are aware of several variants given subspecific or specific rank (Clarke 1980; Conert 1987; Chiapella 2000) or regarded as evolutionary distinct regional units (Peintinger et al. 2012) or narrowly distributed neo-endemics (Heydel et al. 2017). However, for the purpose of this large-scale study we could not collect all those variants that in part may reflect ecotypical differentiation. Following Peintinger et al. (2012), we have separated the D. cespitosa subsp. rhenana (Gremli) Kerguélen and D. cespitosa subsp. littoralis (Gaudin) K.Richter.

Additionally, we have included in this investigation two rare species related to $D$. cespitosa, namely $D$. koelerioides Regel, which was also considered a subspecies of the former by Tzvelev (1976), and $D$. argentea Lowe from Macaronesia which may be an endemic derivative of $D$. cespitosa. These samples were not included in the statistical analyses.

\section{Genome size measurements using flow cytometry (FCM)}

Twenty-five milligrams of fresh or dried leaf tissue was cochopped (Galbraith et al. 1983) along with fresh standard leaf material (Solanum pseudocapsicum L., 1C $=1.295 \mathrm{pg}$; Temsch et al. 2010) in Otto's buffer I (Otto et al. 1981) using a sharp razor blade. The resulting nuclear isolate was filtered through a $30-\mu \mathrm{m}$ nylon mesh. Subsequently, doublestranded RNA was removed by a half an hour treatment with RNase A (Sigma-Aldrich, USA) at $37{ }^{\circ} \mathrm{C}$. Afterward, Otto's buffer II (Otto et al. 1981) that contained $50 \mathrm{mg} / \mathrm{L}$ propidium iodide (PI; AppliChem GmbH, Germany) was added. The preparations were allowed to incubate before measurement for at least $1 \mathrm{~h}$ in the refrigerator or overnight. The samples were measured using a flow cytometer CyFlow ML or CyFlow space (both Sysmex Partec GmbH, Germany), equipped with a diode-pumped laser $(532 \mathrm{~nm}, 100 \mathrm{~mW}$, Cobolt AB, Sweden). The $1 \mathrm{C}$ values of each sample were calculated in respect of a linear relationship between the mean fluorescence intensity (FI) of the G1 nuclei population of the standard and the samples. $1 \mathrm{C}$ value sample $=$ mean FI

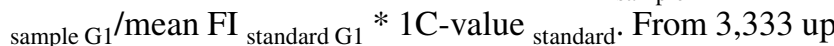
to 10,000 particles were measured per preparation. Means and standard deviations for several runs are given in Table 1. For visualization of different genome sizes, squared decimal size classes were used with genome sizes $<4.1 \mathrm{pg}$ combined in a single class. The DNA ploidy estimated from the FCM data was calibrated by chromosome counts in one tetraploid and two diploid samples.

\section{Chromosome number analyses and Feulgen densitometry (FDM)}

Feulgen densitometry (FDM) was used for chromosome number analyses in order to verify the ploidy level in two diploid and one tetraploid individuals (genome size data not given, Table 1 contains only FCM data of these samples). Root tips were harvested from healthy plantlets of pseudoviviparous plants grown in petri dishes and from samples of seminiferous (seed bearing) plants grown in HBV. For chromosome number analyses, selected root tip meristems were pre-treated with $0.002 \mathrm{M} 8$-hydroxyquinoline in darkness for $2.5 \mathrm{~h}$ at room temperature and $2.5 \mathrm{~h}$ at $4{ }^{\circ} \mathrm{C}$, fixed in methanol/acetic acid (3:1) overnight and stored at $-20^{\circ} \mathrm{C}$ until use. The fixed root tips were washed six times in distilled water together with fixed root tips from an internal standard and hydrolyzed in $5 \mathrm{~N} \mathrm{HCl}$ in an ultra-thermostatic water bath (Model LTD6, Grant Instruments Ltd., Cambridge, Barrington, England) at $20.0^{\circ} \mathrm{C}$ for $60 \mathrm{~min}$. The hydrochloric acid was removed by three washings with distilled water, followed by the staining step with Schiff's reagent (Merck, Darmstadt, Germany) for $1.5 \mathrm{~h}$ at room temperature under light protection. The samples were subsequently washed six times with $\mathrm{SO}_{2}$ water $(0.02 \mathrm{M}$ potassium metabisulfite dissolved in $0.01 \mathrm{~N} \mathrm{HCl}$ ) over a time period of $45 \mathrm{~min}$. Each root tip was squashed in $45 \%$ acetic acid on a slide under a cover slip. After removal of the cover slip, the slides were shortly fixed with ethanol (96\%) and finally air-dried.

The preparations were analyzed using the AxioPlan light microscope (Carl Zeiss, Vienna, Austria) equipped with a CCD black-white camera. Images of the metaphase plates were captured using ZEN software (Carl Zeiss, Vienna, Austria). Genome size was estimated from telophases of the objects and the standard in order to unambiguously assign the ploidy level to the genome size estimates on the basis of single root tips. Therefore, the integrated optical density 


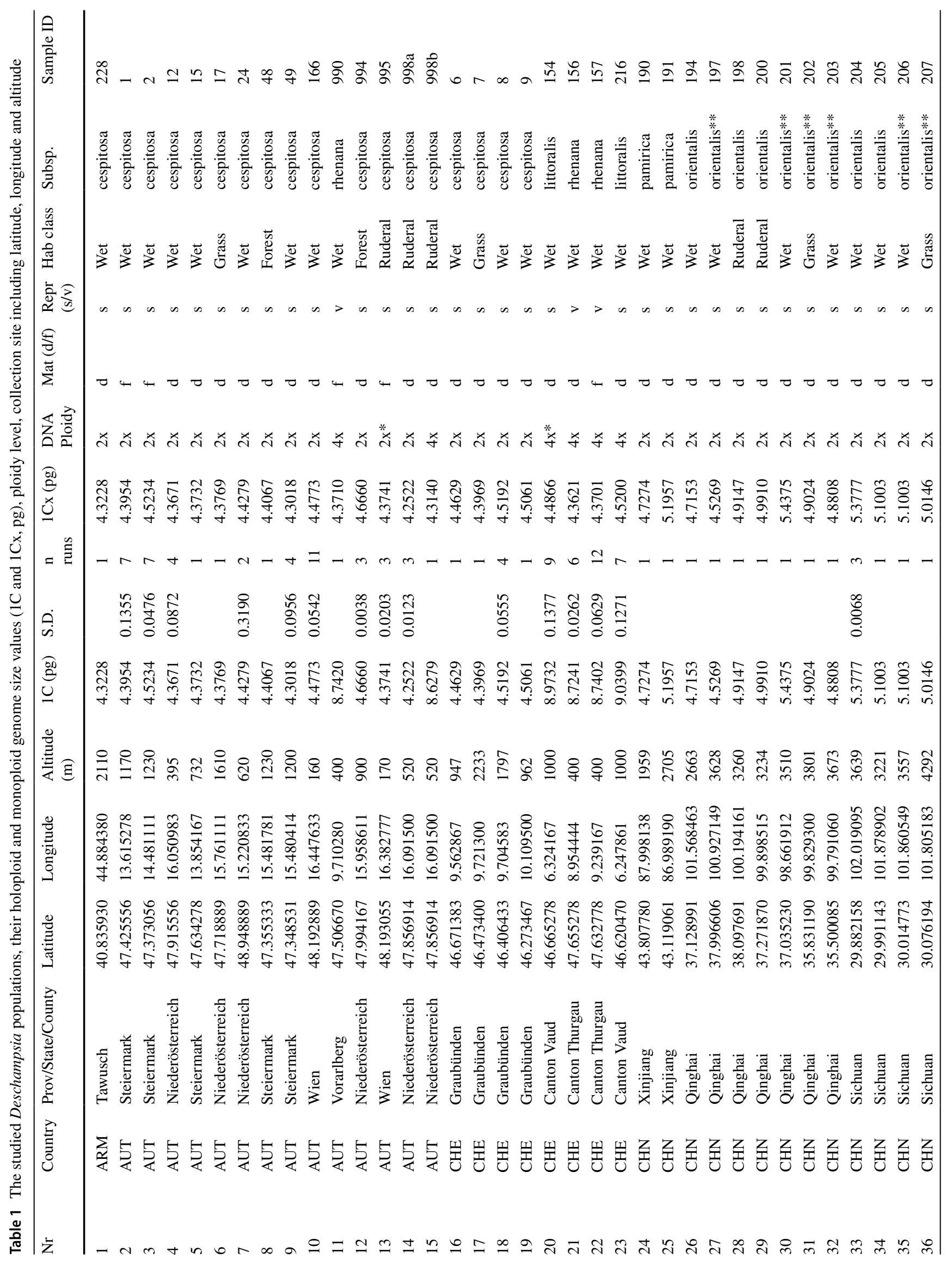




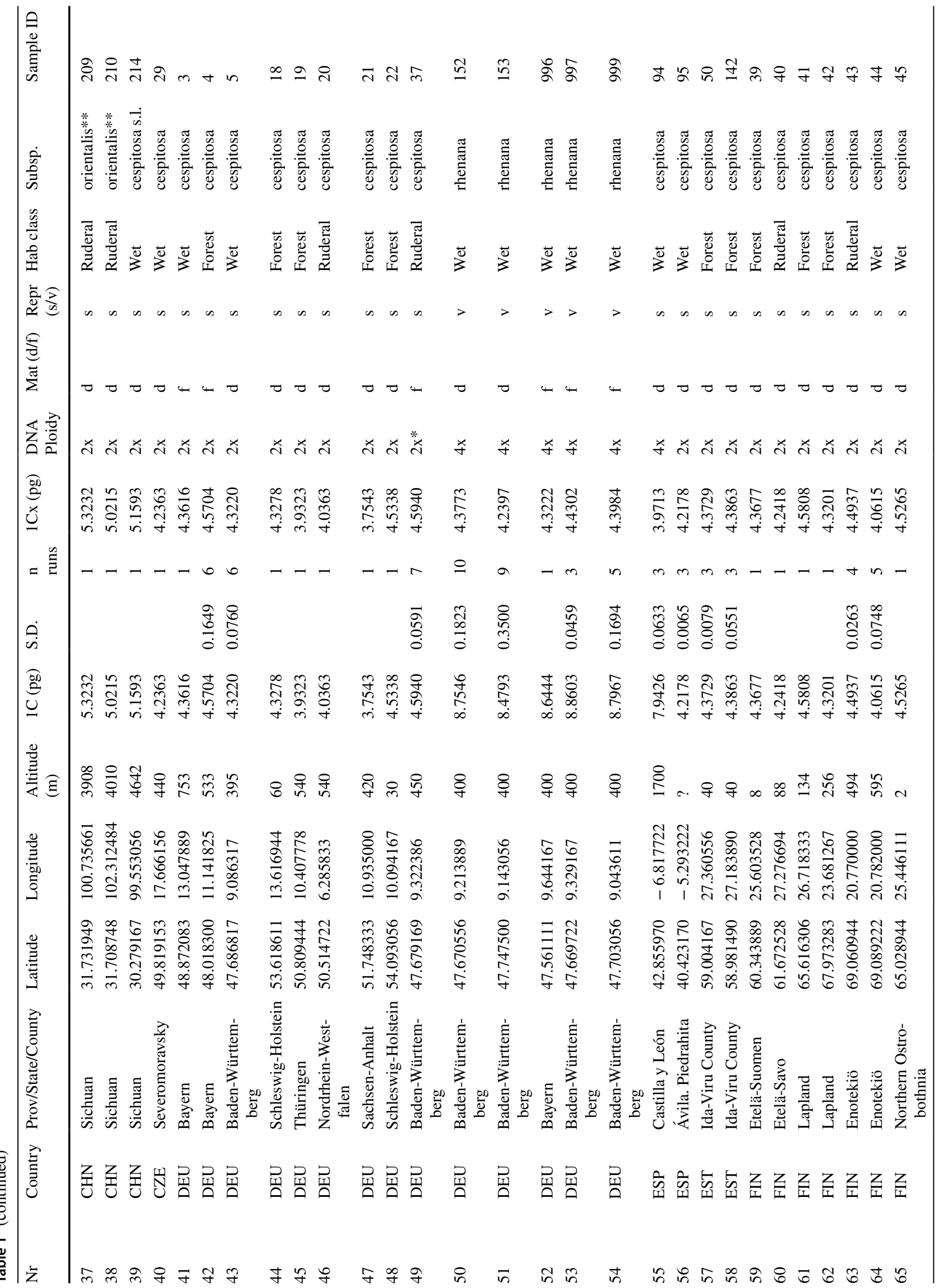




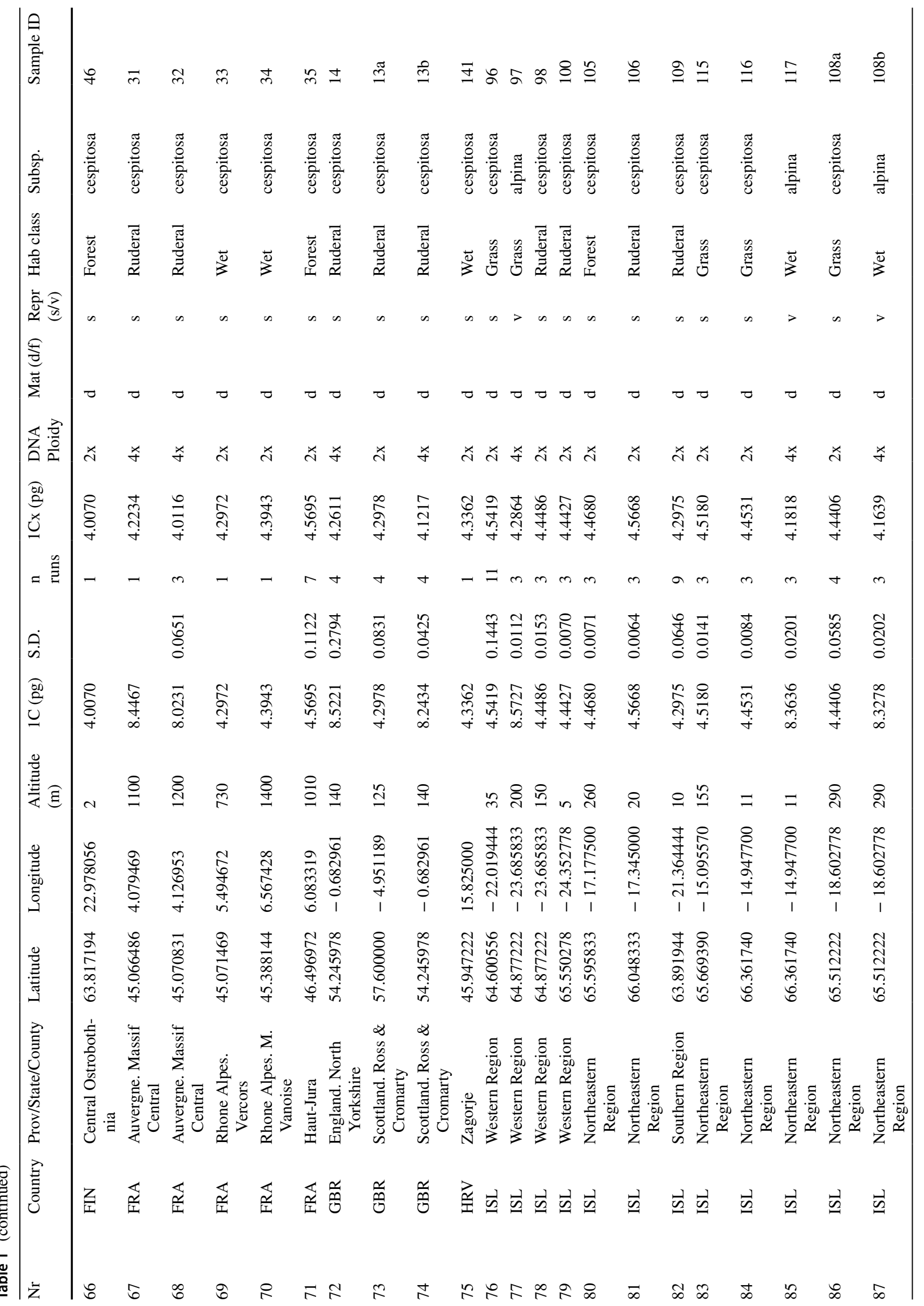




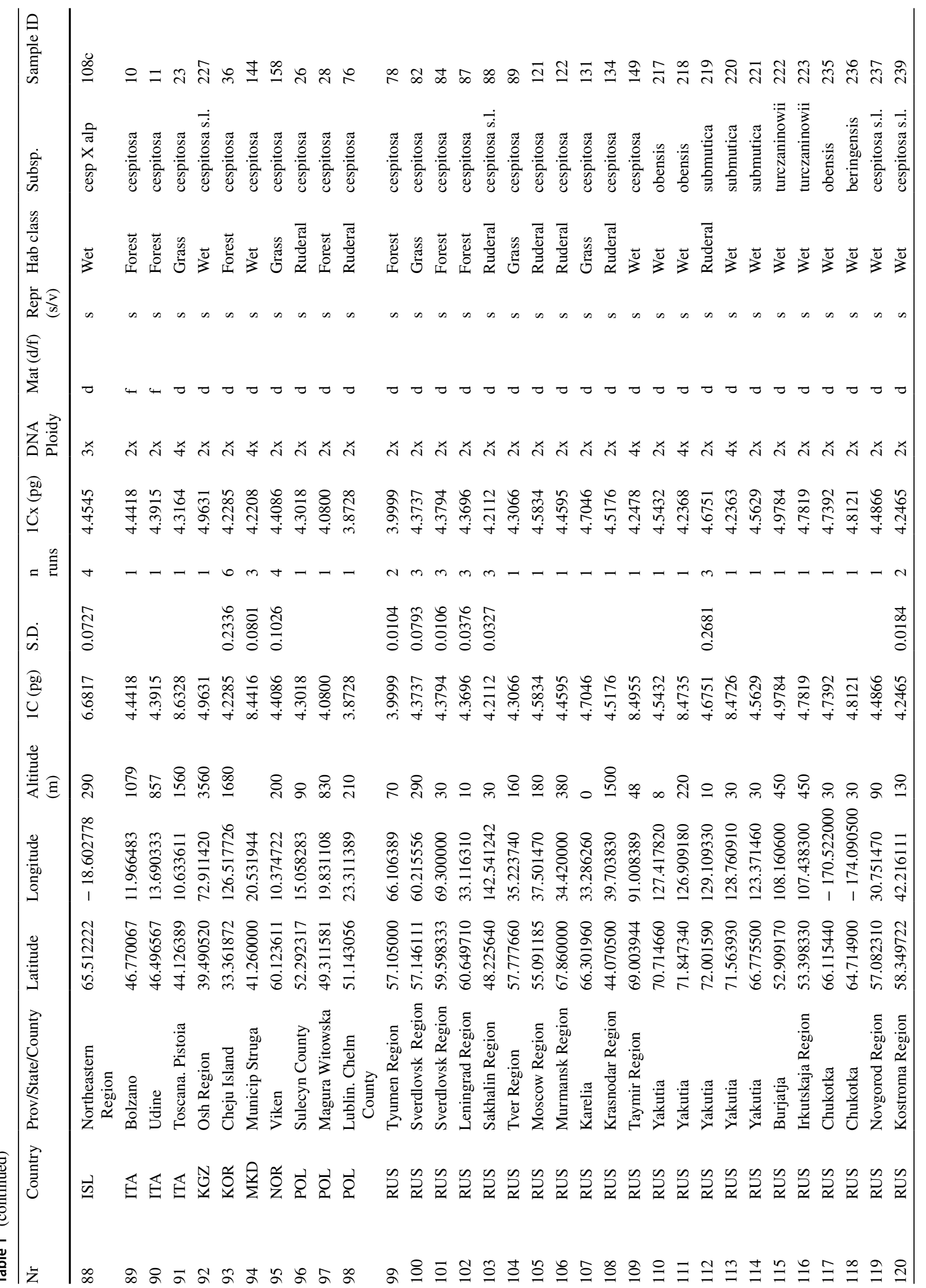




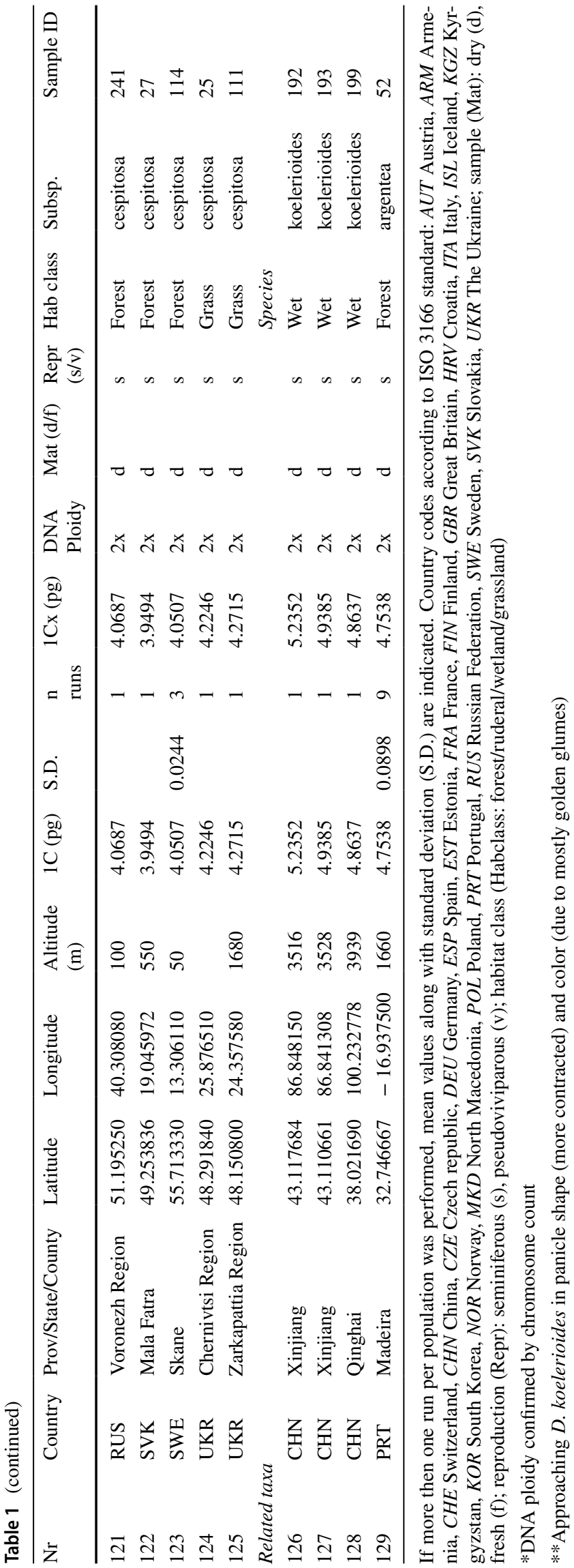

(IOD) was calculated from each nucleus by using the cell image and retrieval system (CIRES, Kontron, Germany) and the genome size estimates were calculated from the linear relationship between the IODs of the objects and the standard, respectively.

\section{Biogeography, habitat and reproductive system}

We have divided the entire Deschampsia cespitosa samples into two regions (Europe and Asia) separated by the 60th degree longitude (Urals). Longitudinal classes covering 10 degrees were applied for visualization of genome size variation related to geography. Four habitat classes (Habclass) based on descriptive sampling data were distinguished: forest (including clearings); grass (meadows, pastures); ruderal (wasteland, roadsides); and wet (wet meadows, lake shores, riverbanks, riparian gravel). Plants were collected in reproductive phase (flowering or with proliferous spikelets), or the reproductive system was determined from monitoring records (observed by MP).

\section{Statistical analysis}

SPSS statistics 25.0 (IBM, Armonk, New York, USA) was used for the analyses and visualization (box plots, bar charts and scatter diagrams) of the overall genome size variation, the variation within the ploidy levels, and its association with habitat classes. Nonparametric options were used to test for differences in sample parameters (Kruskal-Wallis tests). A linear multivariate regression was used to evaluate the effects of altitude, habitat and bioclimatic factors on the genome size of diploid plants. We extracted 19 bioclimatic variables of climate data for each sample location using ArcGIS 10.0.4 from the WorldClim database (Fick and Hijmans 2017; https://worldclim.org/data/worldclim21.html), which are the average for the years 1970-2000 at a resolution of $5 \mathrm{~min}$. We ran pairwise correlation analyses among the 19 bioclimatic variables (BIO1-BIO19) and choose nine with low correlation $(R<0.8)$ which are BIO1 (annual mean temperature), $\mathrm{BIO} 2$ (mean diurnal range), $\mathrm{BIO} 3$ (isothermality), BIO4 (temperature seasonality), BIO5 (max temperature of warmest month), BIO8 (mean temperature of wettest quarter), BIO9 (mean temperature of driest quarter), BIO12 (annual precipitation) and BIO18 (precipitation of warmest quarter). The AIC was employed to determine the best model in stepwise backward multiple regression. The partial effects of each dependent variable in the best model are shown in partial plots according to Grace et al. (2016). 


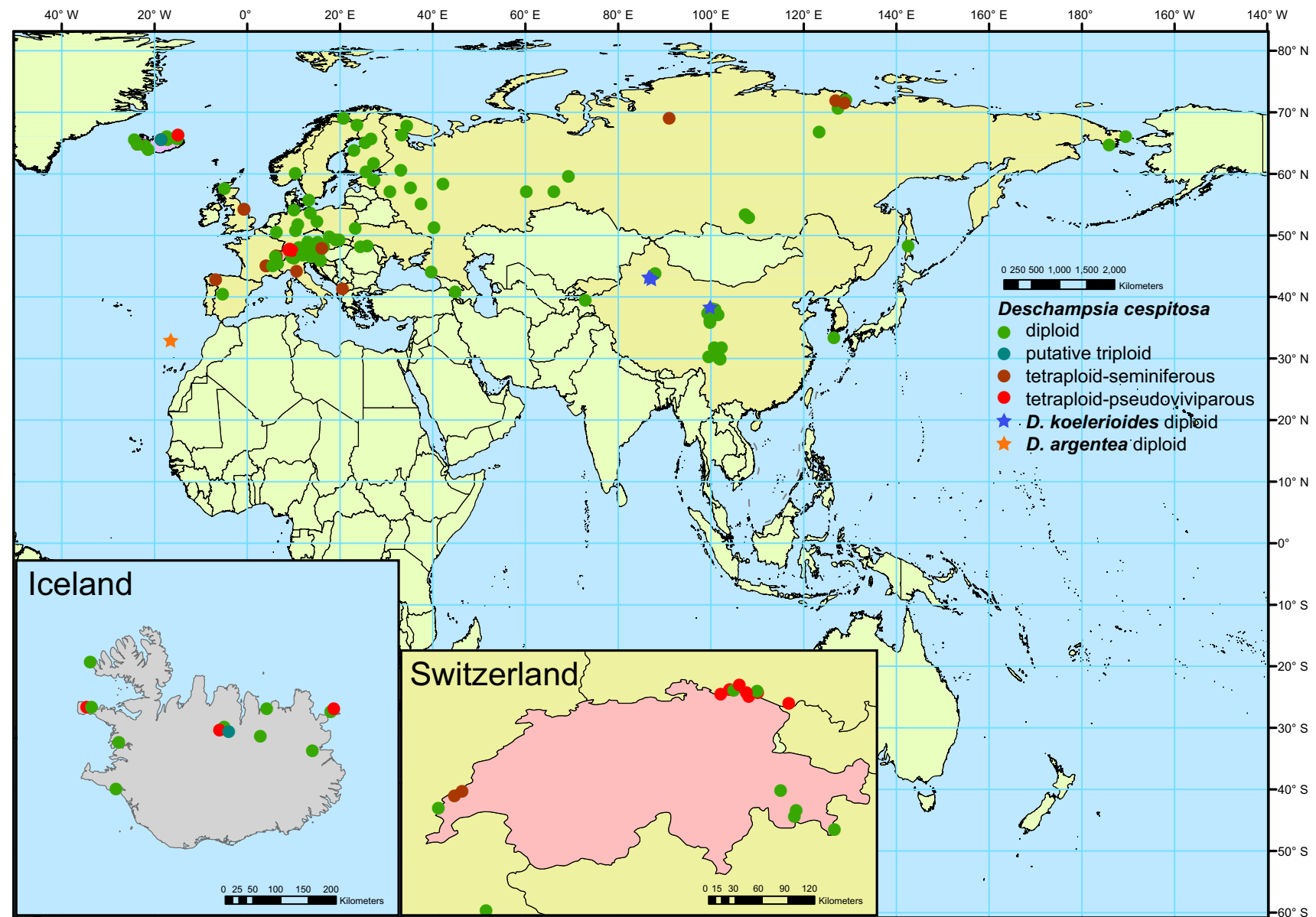

Fig. 1 Map showing the distribution of all Deschampsia samples in Europe and Asia. The map insets depict two regions with dense sampling in Iceland and Switzerland and the region around Lake Constance (including Germany and Austria). The symbols are explained in the map

\section{Results}

\section{Genome size variation and ploidy}

The geographical distribution of the entire sample is shown on the map in Fig. 1. The genome size (1C) ranged from 3.754 to $5.438 \mathrm{pg}$ in diploid and from 7.943 to $8.9732 \mathrm{pg}$ in tetraploid Deschampsia cespitosa (Fig. 2). We report here also the genome size of 4.864-5.235 pg found in $D$. koelerioides and $4.753 \mathrm{pg}$ for $D$. argentea. Genome size data and DNA ploidy of the investigated population samples as revealed by the FCM measurements are provided in Table 1. Mitotic metaphase chromosomes for a diploid plant $(2 n=26,1 \mathrm{C}=4.374 \mathrm{pg})$ of population 13 and a tetraploid plant $(2 n=52,1 \mathrm{C}=8.973 \mathrm{pg})$ of population 20 are shown in Online Resource 3. The genome size of one individual of $6.682 \mathrm{pg}$ suggested a putative DNA triploid, sampled in a mixed population (therefore, different numbers $86-88$ in Table 1) of seminiferous and pseudoviviparous plants. Genome size (1C,pg) clearly varied between diploids,

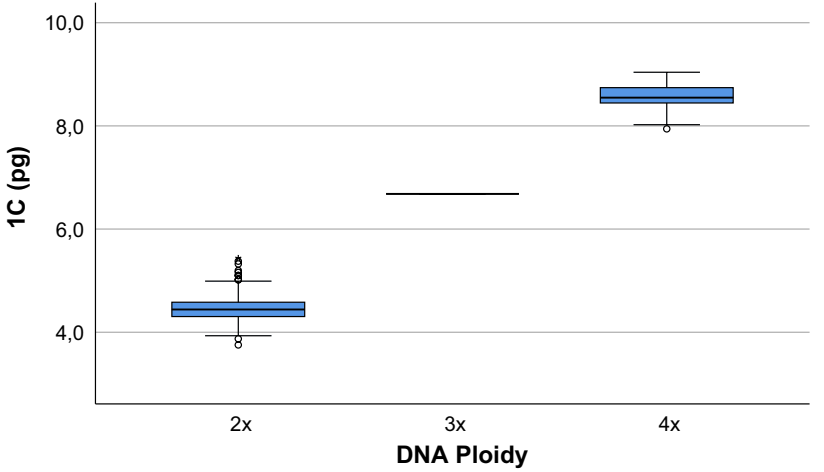

Fig. 2 Variation in genome size of Deschampsia cespitosa (1C, pg) in diploids $(n=100)$, tetraploids $(n=24$; seminiferous and pseudoviviparous) and the putative triploid $(n=1)$

tetraploids and the putative triploid (Fig. 2). The monoploid genome sizes (1Cx, pg) showed geographically structured variation within the diploids, and between some diploids and all tetraploids, but not within tetraploids (Table 1, Fig. 3). 


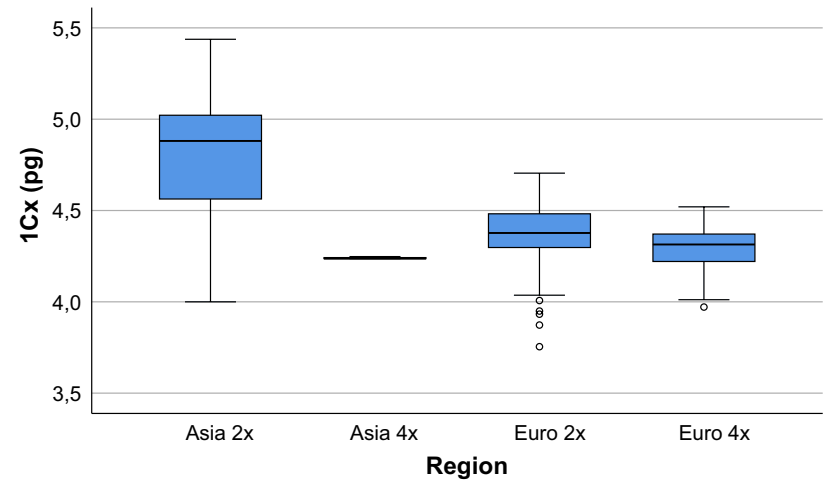

Fig. 3 Variation in monoploid genome size of Deschampsia cespitosa $(\mathrm{Cx}, \mathrm{pg})$ between diploids $(n($ Asia $)=29 ; n($ Europe $)=71)$ and tetraploids $(n($ Asia $)=3 ; n($ Europe $)=21)$

\section{Biogeographic patterns and environmental determinants of genome sizes}

Monoploid genome sizes ( $\mathrm{Cx}, \mathrm{pg})$ of Asian (median $=4.881)$ and European (median $=4.377$ ) diploid populations (Fig. 3) were significantly different $(H=41.441, P<0.001)$. Similarly, Asian diploids and all European tetraploids (median $=4.314)$ were significantly $(H=58.007, P<0.001)$ different. There was a weak although nonsignificant tendency toward smaller genome sizes (i.e., down-sizing) in the European tetraploids compared to the diploids of the same region. The sample of $4 \mathrm{x}$ Asia was too small $(n=3)$ for any meaningful statistics. Variation in monoploid genome size from Western Europe to eastern Asia along longitude classes of 10 degree is shown in Online Resource 4.

While the tetraploid pseudoviviparous variants are clustered in Iceland and around Lake Constance (insets in Fig. 1), the distribution of the tetraploid seminiferous plants did not show a distinct geographic pattern. We found them in southern and Western Europe as well as in Arctic Siberia. No tetraploid seminiferous plants were found in northern Europe and in remaining Asia.

The genome size variation of the entire European and Asian sample of diploid plants was best explained by a model containing altitude, BIO5 (max temperature of warmest month) and BIO12 (annual precipitation). The altitude had a positive effect $\left(R_{\partial}=0.53, P<0.001\right)$, and BIO5 $\left(R_{\partial}=-0.26\right.$, $P<0.001)$ as well as BIO12 $\left(R_{\partial}=-0.25, P=0.011\right)$ had a negative effect on genome size (GS increment/decrement) shown in the partial plots (Fig. 4). The same analysis did not find any significant effect on genome size within the European diploids. European plants with small genomes $(1 \mathrm{C}<4.1 \mathrm{pg})$ were confined to low and moderate altitudes $(<830 \mathrm{~m})$ mainly in temperate latitudes $\left(49-52^{\circ} \mathrm{N}\right)$ of Central Europe, while plants with large genomes were found in the whole range of altitudes being scattered across all the studied area in Europe (Fig. 5a, b).

\section{Ploidy in relation to ecology and reproduction}

Frequencies of diploids and tetraploids considering their reproduction mode were analyzed in the four habitat types (Fig. 6). Both diploids and tetraploids showed a preference for wet habitats. Diploids were found in all environment types, whereas tetraploids were not found in forests. Seminiferous plants were either diploid or tetraploid, while pseudoviviparous plants were only tetraploid. Separating the tetraploids by habitat class, reproduction mode and region indicated the clear preference $(91 \%)$ of pseudoviviparous plants for wet habitats, while a high proportion (50\%) of the nonviviparous western tetraploid plants was found in ruderal habitats (Online Resource 5).
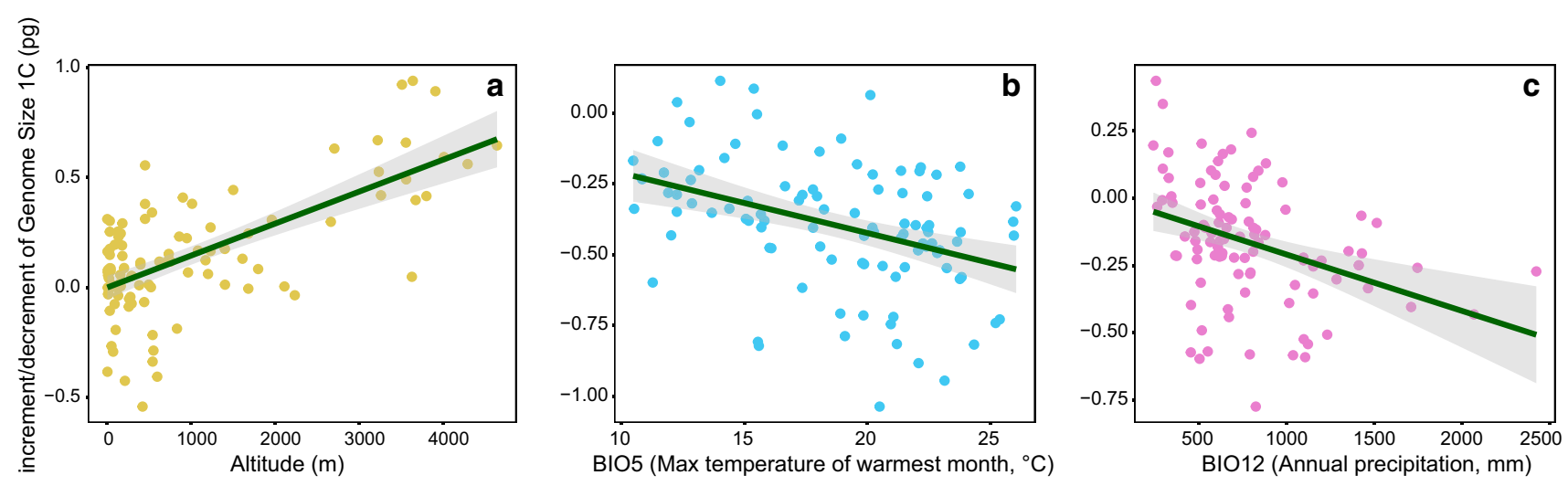

Fig. 4 Plots showing partial effects of predictors on genome size of diploid Deschampsia cespitosa revealed by a multivariate linmonth), and c BIO12 (annual precipitation). Shaded areas represent $95 \%$ confidence intervals 
Fig. 5 Scatter plots showing different genome size classes of diploid Deschampsia cespitosa in relation to geographical longitude ( $x$-axis) and latitude (y-axis)
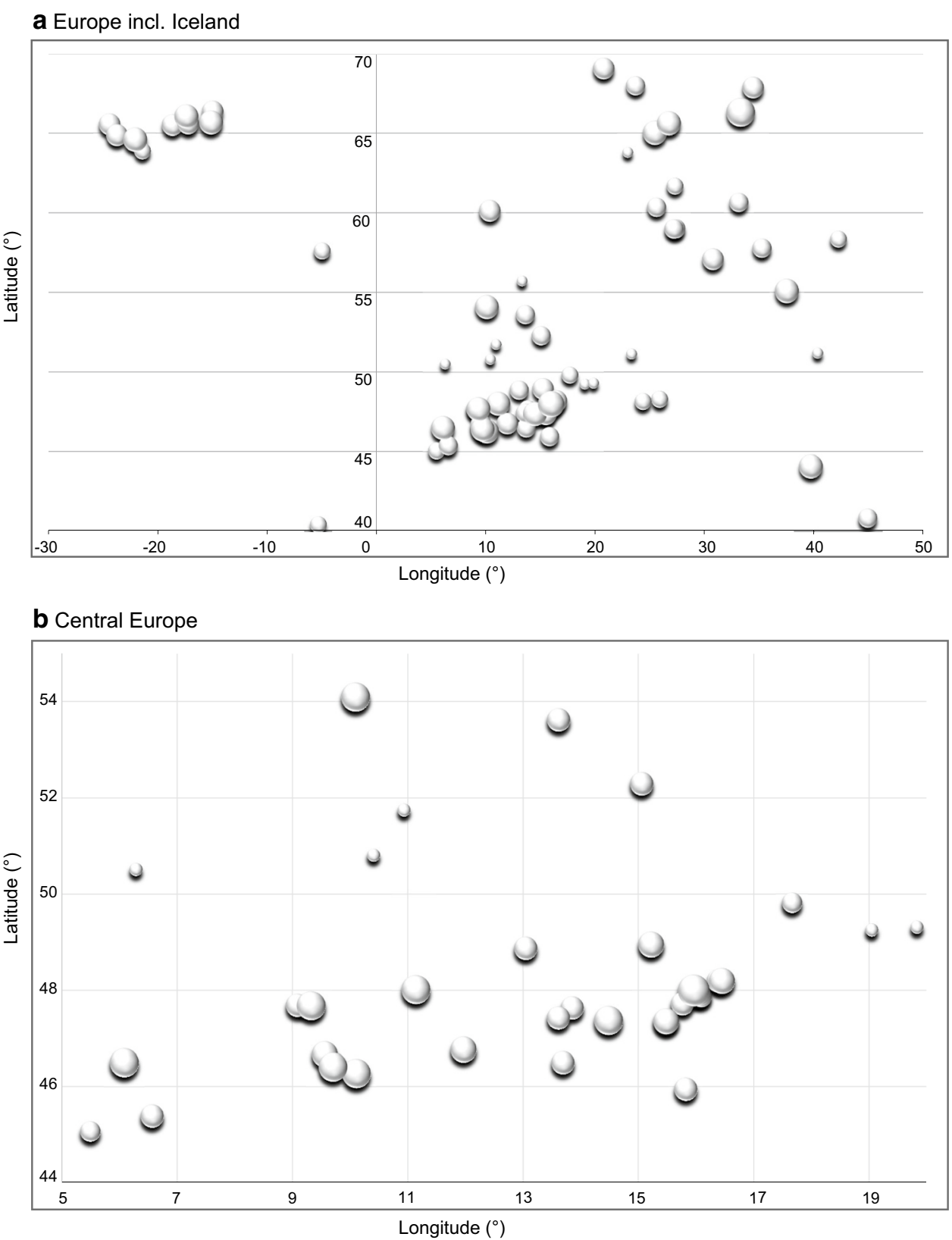

\section{Discussion}

\section{Distribution patterns and ecology of Deschampsia cespitosa in relation to ploidy levels and genome size}

This study confirmed that seminiferous Deschampsia cespitosa is predominantly diploid in Eurasia. In addition, it revealed a pattern of variation in genome size related to biogeography between diploid European and Asian plants. Several tetraploid populations were found, but their number was too low to draw more general conclusions on their distribution apart from the fact that the tetraploid seminiferous plants tended to occur more often in disturbed habitats in Southern and Western Europe and in wet habitats in East Asia, whereas tetraploid pseudoviviparous plants were restricted to periglacial or high-latitude regions and special environments. Diploid D. cespitosa was found in all environments but exhibited a preference for wet habitats. Polyploids were reported to be more common than diploids on the British Isles (Rothera and Davy 1986), and although there was no evidence that they were better adapted to cold environments, they were putatively associated with more disturbed habitats. Given the wide distribution of Subarctic and Arctic variants of diploid D. cespitosa (this paper; Kawano 1963; Tzvelev and Probatova 2019) and 
Habitat class

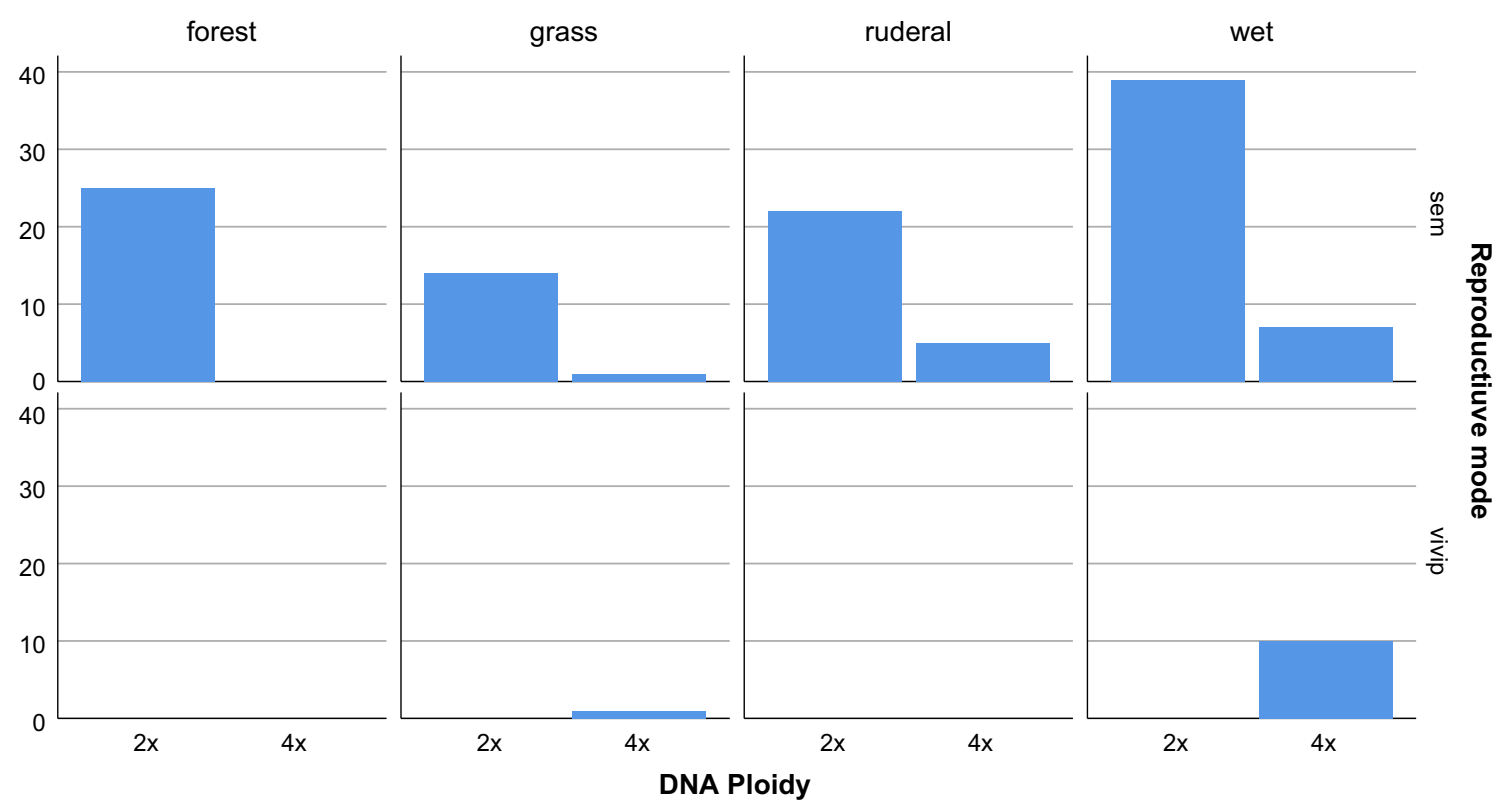

Fig. 6 Numbers of diploid and polyploid Deschampsia cespitos $a$ populations separated by reproduction mode $(\mathrm{sem}=$ seminiferous; vivip = pseudoviviparous) in four habitat classes

the predominance of diploid D. antarctica E.Desv on the Antarctic Peninsula (González et al. 2016; Pascual-Díaz et al. 2020), it is unlikely that temperature alone affected the ploidy levels. Polyploids of various plant groups in arctic regions were hypothesized to be more successful than diploids in post-glacial (re-)colonization (Brochmann et al. 2004). Such polyploids were, however, often found to be of allopolyploid origin, and their success was hypothesized to result from effects of fixed heterozygosity. We do not know whether D. cespitosa tetraploids are of auto- or allopolyploid origin. Further genetic and molecular phylogenetic analyses are needed to infer their origin.

The tetraploid and pseudoviviparous variants/subspecies of our sample were found in lake shore habitats or close to water courses in cold environments. Peintinger et al. (2012) considered the subsp. rhenana around Lake Constance a periglacial relict endemic with special adaptations in its reproduction (facultative pseudovivipary) to flooding and/or very harsh conditions in glacial periods. The other tetraploid and pseudoviviparous subsp. alpina (L.) Tzvelev occurring in the mountains of northern Europe (Clarke 1980) was thought to result from several independent polyploidization events of diploid lineages of $D$. cespitosa with the potential of reproducing by pseudovivipary (Hedberg 1958).

The $\mathrm{C}$ values found for diploid Deschampsia cespitosa were mostly lower than the genome sizes reported for the closely related $D$. antarctica $(1 \mathrm{C}(\mathrm{pg})$ between 5.30 and 5.36: Pascual-Díaz et al. 2020). The trend toward higher genome size in lower (southern) latitudes observed for the diploid
Asian D. cespitosa samples resulted from the higher genome size values of the Chinese samples collected mainly in high altitudes between 3500 and $4000 \mathrm{~m}$. Correlations of genome size and altitude in other plant groups were found to be groupspecific: They were negative in wild relatives of Zea mays L. (Poaceae; Laurie and Bennet 1985; Bilinski et al. 2018) and in Arachis duranensis Krapov \& W.C.Greg (Fabaceae; Temsch and Greilhuber 2001) and positive in Lagenaria siceraria (Molina) Standl (Cucurbitaceae: Achigan-Dako 2008), and no correlation was inferred for Sesleria albicans Kit. ex Schult (Poaceae; Lysak et al. 2000). The association between high genome size, low maximum temperature of the warmest month and low annual precipitation is plausible concerning the moderate temperature. Difficult to interpret is the effect of low precipitation on the genome size; however, Fig. 4c shows a high variation between $<500$ and $1000 \mathrm{~mm}$ that is obviously not well processed by the statistical model. A general caveat is that the coarse grid climate data may not well represent the specific conditions at the collection sites. This concerns especially the Chinese samples (considered different subspecies) as we found Deschampsia mostly close to water courses in the high Chinese mountain ranges (Z.X., H.S., J.G.: pers. obs.). Other investigations found a negative correlation in Liliaceae between genome size and precipitation seasonality (Carta and Peruzzi 2016). Jakob et al. (2004) found disparate genome size patterns in different lineages of Hordeum marinum L. (Poaceae) in association with climatic variables. They concluded that phylogenetic constraints might be more important than ecological determinants. The 
presence of cryptic evolutionary lineages connected to different vegetation history across Europe was inferred to be responsible for the complex patterns of genome size variation within morphologically similar groups of Picris hieracioides L. (Asteraceae; Slovák et al. 2009). This can likely be also the case in D. cespitosa in Europe and on a large continental scale, especially that many of the regional variants have been classified as distinct subspecies (e. g., Conert 1987; Chiapella and Probatova 2003).

No evidence for genome downsizing was found in Europe by comparing monoploid genome sizes of diploids and tetraploids. In Asia, the tetraploid sample was too small for any conclusions. The only significant difference in monoploid genome size was found between the Asian diploids and all other European samples. It may likely represent two different geographically and thus genetically distinct lineages. Further genetic analyses will allow for more insight into this observed pattern.

\section{Ploidy and reproductive mode (seed producing versus pseudovivipary)}

All pseudoviviparous plants investigated in our study had a genome size indicative of DNA tetraploidy. A reproductive switch to pseudovivipary in wild populations was often inferred to be associated with polyploidy and specific environmental conditions (Hedberg 1958; Sarapultsev 2001). Experimentally induced environmental stress (short-time daylight) was reported to trigger a switch from seminiferous to pseudoviviparous reproduction in D. cespitosa (Nygren 1949); however, the association with polyploidy was not tested. There is only a scarce record of diploid and pseudoviviparous variants of Deschampsia. An experimentally induced switch to this reproductive mode was observed in diploid European accessions transplanted to transects in California (Lawrence 1945). Another diploid plant collected in the wild with pseudoviviparous reproduction was reported by Hedberg (1958). A few diploid chromosome numbers were also reported for samples assigned to the usually tetraploid and pseudoviviparous northern variant (subsp. alpina), however, without reference to the reproductive mode (Kawano 1963). One of these records refers to a diploid chromosome number in a seminiferous accession under the name $D$. alpina Roem. ex Schult which was hypothesized to be a potentially slender variety of $D$. cespitosa s. str. (Nygren 1949).

\section{Conclusions}

Seminiferous Deschampsia cespitosa s.l. is mostly diploid throughout Eurasia. However, a high variation $(\mathrm{CV} \%=7.24)$ in genome size was found among the diploid populations across the geographic west-east gradient in Eurasia. Genome size was significantly lower in European accessions than in the Asian ones. Tetraploids of seminiferous plants were often found on disturbed habitats, albeit without any geographically or ecologically consistent pattern in their distribution. Pseudovivipary was found to be specific only to polyploids and associated with habitats of high moisture.

\section{Information on Electronic Supplementary Mate- rial}

Online Resource 1. Performance test of two Deschampsia cespitosa samples in FCM analysis during five months.

Online Resource 2. Classification of Deschampsia in Europe and Asia. Online Resource 3. Mitotic metaphase chromosomes of Deschampsia cespitosa.

Online Resource 4. Regional variation in monoploid genome size of Deschampsia cespitosa.

Online Resource 5. Polyploids of Deschampsia cespitosa in relation to reproduction mode, habitat class, and region.

Supplementary Information The online version contains supplementary material available at https://doi.org/10.1007/s00606-021-01796-7.

Acknowledgements For help in additional collecting, we thank Liudmila Abramova, Svetlana Chinenko, Christian Gilly, Karin GreimlerStocker, Maxim Grigorian, Yu-Feng Gu, Jun-Hao Yu, Michael Hedrén, Markus Hofbauer, Chang-Gee Jang, Sanja Kovacic, Olga Mochalova, Clemens Pachschwöll, Ovidiu Paun, Dieter Reich, Ruth Sander, Peter Schönswetter, Yevgenii Sosnovskyi, Nikita Tikhomirov, Andreas Tribsch, Kai Vellak, Alla Verkhozina, Thomas Wilhalm, the staff of Nizhnesvirinskii Russian natur reserve, the expedition of South-West-High School \# 1543, and the staff of Lomonosov Moscow State University. We are grateful to Michael Münch and the Botanical Gardens of the Universities of Vienna and Konstanz.

Author contributions All authors contributed to the study conception and design. Material collection and preparation were performed by JG, ZX, PV, MP, PW, IS, HS and JOC. Analyses in the laboratory were performed by EMT and HWS, and data analyses were performed by EMT, JG, ZX, HS and PV. The first draft of the manuscript was written by JG and EMT, and all authors commented on previous versions of the manuscript. All authors read and approved the final manuscript.

Funding Open access funding provided by University of Vienna. This research was supported by the Austrian Science Fund (FWF grant P30208-B-29 to JG and JOC) and the China Scholarship Council (CSC) No. 201804910630 to ZX. The work of PV was supported by the Russian Foundation for Basic Research (Project 19-04- 01090a) and was held within the state assignment of IBIW RAS (theme 121051100099-5). The work of IS was held within the state assignment of MBG RAS \#19-119012390082-6 and support by Ministry of Science and Higher Education of Russia with CCU "Herbarium MBG RAS”, grant 075-15-2021-678.

\section{Declarations}

Conflict of interest The authors declare that they have no conflict of interest. 
Open Access This article is licensed under a Creative Commons Attribution 4.0 International License, which permits use, sharing, adaptation, distribution and reproduction in any medium or format, as long as you give appropriate credit to the original author(s) and the source, provide a link to the Creative Commons licence, and indicate if changes were made. The images or other third party material in this article are included in the article's Creative Commons licence, unless indicated otherwise in a credit line to the material. If material is not included in the article's Creative Commons licence and your intended use is not permitted by statutory regulation or exceeds the permitted use, you will need to obtain permission directly from the copyright holder. To view a copy of this licence, visit http://creativecommons.org/licenses/by/4.0/.

\section{References}

Achigan-Dako E, Ndanikou S, Ahanchede A, Ganglo J, Blattner F (2008) Phenetic analysis of wild populations of Momordica charantia L. (Cucurbitaceae) in West Africa and inference of the definition of the new subspecies macroloba Achigan-Dako and Blattner. Candollea 63:153-167

Albers F (1975) Pollenmorphologie und Chromosomenzahlen der Poaceen-Subtribus Deschampsia Holub. Grana 15:7-17

Albers F (1980) Vergleichende Karyologie der Gräser-Subtriben Aristaveninae und Airinae (Poaceae-Aveneae). Pl Syst Evol 136:137-167. https://doi.org/10.1007/BF01004624

Amosova AV, Bolsheva NL, Samatadze TE, Twardovska MO, Zoshchuk SA, Andreev IO, Badaeva ED, Kunakh VA, Muravenko OV (2015) Molecular cytogenetic analysis of Deschampsia antarctica Desv. (Poaceae) Maritime Antarctic. PLOS ONE 10:e138878. https://doi.org/10.1371/journal.pone.0138878

Amosova AV, Bolsheva NL, Zoshchuk SA, Twardovska MO, Yurkevich OY, Andreev IO, Samatadze TE, Badaeva ED, Kunakh VA, Muravenko OV (2017) Comparative molecular cytogenetic characterization of seven Deschampsia (Poaceae) species. PLOS ONE 12:e175760. https://doi.org/10.1371/journal.pone.0175760

Bennett MD, Smith JB, Smith RIL (1982) DNA amounts of angiosperms from the Antarctic and South Georgia. Environm Exp Bot 22:307-318. https://doi.org/10.1016/0098-8472(82)90023-5

Bilinski P, Albert PS, Berg JJ, Birchler JA, Grote MN, Lorant A, Quezada J, Swarts K, Yang J, Ross-Ibarra J (2018) Parallel altitudinal clines reveal trends in adaptive evolution of genome size in Zea mays. PLOS Genet 14:e1007162. https://doi.org/10.1371/journal. pgen. 1007162

Böcher TW, Holmen K, Jakobsen K (1968) The flora of Greenland. P. Haase and Son, Copenhagen Denmark

Brochmann C, Brysting AK, Alsos IG, Borgen L, Grundt HH, Scheen AC, Elven R (2004) Polyploidy in arctic plants. Biol J Linn Soc 82:521-536. https://doi.org/10.1111/j.1095-8312.2004.00337.x

Carta A, Peruzzi L (2016) Testing the large genome constraint hypothesis: plant traits, habitat and climate seasonality in Liliaceae. New Phytol 210:709-716. https://doi.org/10.1111/nph.13769

Chiapella J (2000) The Deschampsia cespitosa complex in Central and Northern Europe: a morphological analysis. Bot J Linn Soc 134:495-512. https://doi.org/10.1111/j.1095-8339.2000.tb005 47. $\mathrm{x}$

Chiapella J, Probatova NS (2003) The Deschampsia cespitosa complex (Poaceae: Aveneae) with special reference to Russia. Bot J Linn Soc 142:213-228. https://doi.org/10.1046/j.1095-8339. 2003.00167.x

Chiapella J, Zuloaga FO (2010) A revision of Deschampsia, Avenella, and Vahlodea (Poaceae, Poeae, Airinae) in South America. Ann Missouri Bot Gard 97:141-162. https://doi.org/10.3417/2008115
Clarke GCS (1978) Deschampsia Bauv. In: Heywood VH (ed) Flora Europaea. Notulae Systematicae ad Floram Europaeam spectantes 20. Bot J Linn Soc 76: 362-363.

Clarke GCS (1980) Deschampsia (L.) P.Bauv. In: Tutin TG, Heywood VH, Burges NA, Moore DM, Valentine DH, Walters SM, Webb DA (eds) Flora Europaea 5. Cambridge University Press, Cambridge, pp 225-227

Conert HJ (1987) Deschampsia. In: Hegi G (ed) Illustrierte Flora von Mitteleuropa, Band 1, Teil 3. Parey Buchverlag, Berlin, pp 302-317

Czerepanov SK (1995) Vascular plants of Russia and adjacent states (the former USSR). Cambridge University Press, Cambridge

Dobeš C, Vitek E (2000) Documented chromosome number checklist of Austrian vascular plants. Verlag des Naturhistorischen Museum, Wien

Eilam T, Anikster Y, Millet E, Manisterski J, Feldman M (2009) Genome size in natural and synthetic autopolyploids and in a natural segmental allopolyploid of several Triticeae species. Genome 52:275-285. https://doi.org/10.1139/G09-004

Fick SE, Hijmans RJ (2017) WorldClim 2: new 1km spatial resolution climate surfaces for global land areas. Int J Climatol 37:43024315. https://doi.org/10.1002/joc.5086

Galbraith DW, Harkins KR, Maddox JM, Ayres NM, Sharma DP, Firoozabady E (1983) Rapid flow cytometric analysis of the cell cycle in intact plant tissues. Science 220:1049-1051. https://doi. org/10.1126/science.220.4601.1049

Garcia-Suarez R, Alonso-Blanco C, Fernandez-Carvajal MC, Fernandez-Prieto JA, Roca A, Giraldez R (1997) Diversity and systematics of Deschampsia sensu lato (Poaceae), inferred from karyotypes, protein electrophoresis, total genomic DNA hybridization and chloroplast DNA analysis. Pl Syst Evol 205:99-110

González ML, Urdamopilleta JD, Fasanella M, Premoli AC, Chiapella JO (2016) Distribution of rDNA and polyploidy in Deschampsia antarctica E. Desv. in Antarctic and Patagonic populations. Polar Biol 39:1663-1677. https://doi.org/10.1007/s00300-016-1890-5

Grace JB, Anderson TM, Seabloom EW, Borer ET, Adler PB, Harpole WS, Hautier Y, Hillebrand H, Lind EM, Pärtel M, Bakker JD, Buckley YM, Crawley MJ, Damschen EI, Davies KF, Fay PA, Firn J, Gruner DS, Hector A, Knops JMH, MacDougall AS, Melbourne BA, Morgan JW, Orrock JL, Prober SM, Smith MD (2016) Integrative modelling reveals mechanisms linking productivity and plant species richness. Nature 529:390-393. https://doi.org/ 10.1038 /nature 16524

Hedberg O (1958) Cytotaxonomic studies in Scottish mountain plants, notably Deschampsia caespitosa (L.) PB.s.lat. Sven Bot Tidskr 52:37-46

Heydel F, Engels JG, Feigs JT, Vásquez E, Rudolph B, Rohwer JG, Jensen K (2017) Adaptation to tidal flooding and rapid genetic divergence between a narrow endemic grass species and its widespread congener lead to an early stage of ecological speciation. Perspect Pl Ecol Evol Syst 27:57-67. https://doi.org/10.1016/j. ppees.2017.05.001

Jakob SS, Meister A, Blattner FR (2004) The considerable genome size variation of Hordeum Species (Poaceae) is linked to phylogeny, life form, ecology and speciation rates. Molec Biol Evol 21:860-869. https://doi.org/10.1093/molbev/msh092

Jiao Y, Wickett NJ, Ayyampalayam S, Chanderbali AS, Landherr L, Ralph PE, Tomsho LP, Hu Y, Liang H, Soltis PS, Soltis DE, Clifton SW, Schlarbaum SE, Schuster SC, Ma H, Leebens-Mack J, dePamphilis CW (2011) Ancestral polyploidy in seed plants and angiosperms. Nature 473:97-100. https://doi.org/10.1038/ nature09916

Kawano S (1963) Cytogeography and evolution of the Deschampsia cespitosa complex. Canad J Bot 41:719-742

Keeler KH, Davis GA (1999) Comparison of common cytotypes of Andropogon gerardii (Andropogoneae: Poaceae). Amer J Bot 86:974-979. https://doi.org/10.2307/2656614 
Kellogg EA (2015) Karyology and Genome Structure. In: Kellogg EA (ed) Flowering Plants. Monocots The Families and Genera of Vascular Plants 13. Springer International Publishing, Switzerland, pp 55-61.

Lauber K, Wagner G (1998) Flora Helvetica. Haupt Verlag, Bern

Laurie DA, Bennet MD (1985) Nuclear DNA content in the genera Zea and Sorghum. Intergeneric, interspecific and intraspecific variation. Heredity 55:307-313. https://doi.org/10.1038/hdy.1985.112

Lawrence WE (1945) Some ecotypic relations in Deschampsia cespitosa. Amer J Bot 32:298-314

Löve Ä, Löve D (1975) Cytotaxonomical atlas of the Slovenian flora. Cramer, Königstein

Lysák MA, Rostková A, Dixon JM, Rossi G, Doležel J (2000) Limited Genome Size Variation in Sesleria albicans. Ann Bot (Oxford) 86:399-403. https://doi.org/10.1006/anbo.2000.1200

Marhold K, Martonfi P, Mereda P jun, Mraz P (Eds) (2007) Chromosome number survey of the ferns and flowering plants of Slovakia. VEDA, Bratislava.

Murray BG, De Lange PJ, Ferguson AR (2005) Nuclear DNA variation, chromosome numbers and polyploidy in the endemic and indigenous grass flora of New Zealand. Ann Bot (Oxford) 96:12931305. https://doi.org/10.1093/aob/mci281

Nygren A (1949) Studies on vivipary in the genus Deschampsia. Hereditas 35:27-32

Otto FJ, Oldiges H, Goehde W, Jain VK (1981) Flow cytometric measurement of nuclear DNA content variations as a potential in vivo mutagenicity test. Cytometry 2:189-191. https://doi.org/10.1002/ cyto. 990020311

Pascual-Díaz JP, Serce S, Hradecká I, Vanek M, Özdemir BS, Sultana N, Vural M, Vitales D, Garcia S (2020) Genome size constancy in Antarctic populations of Colobanthus quitensis and Deschampsia antarctica. Polar Biol 43:1407-1413. https://doi.org/10.1007/ s00300-020-02699-y

Peintinger M, Arrigo N, Brodbeck S, Koller A, Imsand M, Holderegger R (2012) Genetic differentiation of the endemic grass species Deschampsia littoralis at Pre-Alpine Lakes. Alpine Bot 122:87-93. https://doi.org/10.1007/s00035-012-0107-y

Porsild AE, Cody WJ (1980) Vascular plants of continental northwest territories, Canada. National Museums of Canada, Ottawa

Probatova NS (1985) Poaceae. In: Kharkevich SS (ed) Vascular plants of the Soviet Far East. Nauka Publishing House, Leningrad, pp 89-382 (in Russian)

Rothera SL, Davy AJ (1986) Polyploidy and habitat differentiation in Deschampsia cespitosa. New Phytol 102:449-467. https://doi.org/ 10.1111/j.1469-8137.1986.tb00822.x

Ruprecht C, Lohaus R, Vanneste K, Mutwil M, Nikoloski Z, Van de Peer Y, Persson S (2017) Revisiting ancestral polyploidy in plants. Sci Advances 3:e1603195. https://doi.org/10.1126/sciadv.1603195

Saarela JM, Bull RD, Paradis MJ, Ebata SN, Peterson PM, Soreng RJ, Paszko B (2017) Molecular phylogenetics of cool-season grasses in the subtribes Agrostidinae, Anthoxanthinae, Aveninae, Brizinae, Calothecinae, Koeleriinae and Phalaridinae (Poaceae, Pooideae, Poeae, Poeae chloroplast group 1). PhytoKeys 87:1-139. https://doi.org/10.3897/phytokeys.87.12774
Sarapultsev IE (2001) The Phenomenon of Pseudoviviparity in Alpine and Arctomontane Grasses (Deschampsia Beauv., Festuca L., and Poa L.). Russ J Ecol 32:170-178. https://doi.org/10.1023/A:10113 58026992

Slovák M, Vít P, Urfus T, Suda J (2009) Complex pattern of genome size variation in a polymorphic member of the Asteraceae. J Biogeogr 36:372-384. https://doi.org/10.1111/j.1365-2699.2008. 02005.x

Sokolovskaya AP, Probatova NS (1975) Chromosome numbers of some grasses (Poaceae) of the flora of USSR. Bot Zhurn 60:667-678 (in Russian)

Soltis DE, Segovia-Salcedo MC, Jordon-Thaden I, Majure L, Miles NM, Mavrodiev EV, Mei W, Cortez MB, Soltis PS, Gitzendanner MA (2014) Are polyploids really evolutionary dead-ends (again)? A critical reappraisal of Mayrose et al. (2011). New Phytol 202:1105-1117

Soreng RJ, Peterson PM, Romaschenko K, Davidse G, Zuloaga FO Judziewicz EJ, Filgueiras TS, Davis JI, Morrone O (2015) A worldwide phylogenetic classification of the Poaceae (Gramineae). J Syst Evol 53:117-137. https://doi.org/10.1111/jse.12150

Temsch EM, Greilhuber J (2001) Genome size in Arachis duranensis: A critical study. Genome 44:826-830. https://doi.org/10.1139/ g01-081

Temsch EM, Greilhuber J, Krisai R (2010) Genome size in liverworts. Preslia 82:63-80

Tzvelev NN (1976) Grasses of the Soviet Union, vol. 2. Amerind Publishing Co., New Delhi

Tzvelev NN, Probatova NS (2012) The taxonomic revision of the genera Deschampsia, Agrostis, Calamagrostis (Poaceae: Poeae) and the system of grasses in the flora of Russia. V. L. Komarov Memorial Lectures. Vladivostok: Dalnauka 59:7-75 (in Russian)

Tzvelev NN, Probatova NS, Chiapella J (2015) New taxa of Deschampsia P. Beauv. (Poaceae) from Russia. Botanica Pacifica 4:1-6.

Tzvelev NN, Probatova NS (2019) Grasses of Russia. KMK Scientific Press, Moscow

Weiss-Schneeweiss H, Schneeweiss G (2013) Karyotype diversity and evolutionary trends in Angiosperms. Pl Genome Diversity 2:209-230. https://doi.org/10.1007/978-3-7091-1160-4_13

Wendel JF, Lisch D, Hu G, Mason AS (2018) The long and short of doubling down: polyploidy, epigenetics, and the temporal dynamics of genome fractionation. Curr Opin Genet Developm 49:1-7. https://doi.org/10.1016/j.gde.2018.01.004

Wölk A, Röser M (2017) Hybridization and long-distance colonization in oat-like grasses of South and East Asia, including an amended circumscription of Helictotrichon and the description of the new genus Tzveleviochloa (Poaceae). Taxon 66:20-23. https://doi.org/ $10.12705 / 661.2$

Wu Z, Phillips SM (2006) 80. Deschampsia P. Beauvois. Zhengyi W, Raven PH, Deyuan H (eds) Flora of China, vol. 22: Poaceae. Science Press and Missouri Botanical Garden, Beijing and St. Louis, pp 332-334

Publisher's Note Springer Nature remains neutral with regard to jurisdictional claims in published maps and institutional affiliations. 